\title{
LANSKAP ARKEOLOGI DALAM PERSPEKTIF PROSESUAL DAN PASCA-PROSESUAL: STUDI KASUS KOMPLEKS MEGALITIK DI DATARAN TINGGI JAMBI
}

\section{LANDSCAPE OF ARCHAEOLOGY IN PROCESSUAL AND POSTPROCESSUAL PERSPECTIVES: CASE STUDY ON MEGALITHIC COMPLEX IN JAMBI HIGHLAND}

\author{
Hafiful Hadi Sunliensyar \\ Mahasiswa S2 IImu Arkeologi, Fakultas IImu Budaya \\ Universitas Gadjah Mada \\ hafifulhadi222@gmail.com
}

\begin{abstract}
The development of archaeology paradigm from processual to postprocessual was influencing the archaeologists thought about landscape. Sometimes, the landscape in archaeology is not easily understood because it is overlapping with other studies. Actually, this problem can be solved if we analyze the development of archaeology paradigm which associated with landscape study. This article attempts to discuss the ambiguity of landscape in archaeology using a case study on the megalithic complex in Jambi Highland. Based on the data, it is known that: landscape in procesual study was just explaining the association between megalithic with burial-jars, mountains, settlements, and natural resources around it. The result which was obtained using this perspective, was an explanation of megalithic function based on the relationship between sites and environment. In the other hand, the post-processualist attempts to interpret megalithic complex in Jambi Higland based on individual (including the researcher's) or community perceptions. The result obtained in postprocessual, is able to answer questions about the unevenness of megalithic orientation and the difference of their locations.
\end{abstract}

Keywords: Megalithic, Landscape, Jambi, Processual, Postprocessual.

\begin{abstract}
ABSTRAK
Perkembangan paradigma arkeologi dari prosesual ke pasca-prosesual turut pula memengaruhi pemikiran para arkeolog tentang lanskap. Lanskap dalam kajian arkeologi terkadang sulit dipahami karena dianggap tumpang tindih dengan bidang kajian lain, misalnya dengan kajian arkeologi lingkungan. Oleh sebab itu, konsep lanskap arkeologi oleh beberapa ilmuwan sering disebut sebagai konsep ambigu. Padahal seyogyanya, persoalan ini bisa diatasi bila kita menelaah perkembangan paradigma arkeologi dalam kaitannya dengan penelitian tentang lanskap. Tulisan ini berupaya mengupas persoalan tersebut dengan mengambil kasus pada distribusi megalitik di Dataran Tinggi Jambi. Distribusi megalitik ini dikaji dengan menggunakan dua kerangka pikir yang berbeda yaitu prosesual dan pasca-prosesual. Tujuannya adalah untuk melihat perbedaan hasil yang diperoleh saat menggunakan paradigma yang berbeda meskipun pada objek yang sama. Berdasarkan telaah terhadap data yang diperoleh melalui studi kepustakaan didapatkan hasil bahwa: kajian lanskap secara prosesual hanya mampu menjelaskan hubungan antara megalitik dengan kubur tempayan, gunung, permukiman, sumberdaya alam di sekitarnya. Hasil yang diperoleh dalam kerangka paradigma ini adalah penjelasan mengenai fungsi megalitik dengan melihat relasi antar situs maupun situs dengan lingkungannya. Sebaliknya dalam perspektif pasca-prosesual, berupaya menginterpretasi tinggalan megalitik baik dari sudut pandang individu seperti peneliti sendiri maupun kelompok seperti komunitas di sekitar megalitik. Hasil yang didapat melalui perspektif ini, mampu menjawab permasalahan ketidakseragaman arah orientasi dan perbedaan lokasi penempatan megalitik berdasarkan legenda, tradisi lisan dan kosmologi.
\end{abstract}

Kata Kunci: Megalitik, Lanskap, Jambi, Prosesual, Pasca-prosesual.

Tanggal Masuk : 15 Agustus 2018

Tanggal Diterima : 22 Januari 2019 


\section{PENDAHULUAN}

Secara umum, arkeologi didefinisikan sebagai ilmu yang mempelajari kehidupan masa lampau melalui tinggalan-tinggalannya yang berwujud artefak, ekofak dan fitur. Melalui tinggalan-tinggalan tersebut arkeolog merekonstruksi sejarah kebudayaan, cara-cara hidup dan perilaku manusia, serta perubahanperubahan budaya di masa lampau. Dalam arti luas, arkeologi tidak terbatas mempelajari budaya, tetapi juga manusia dan lingkungannya, tiga elemen yang tidak terpisahkan antara satu sama lain (Simanjuntak, 2008 dalam wawancara dengan Majalah DIA).

Sebagai disiplin ilmu, sudah barang tentu arkeologi membutuhkan berbagai pendekatan untuk menjawab permasalahanpermasalahan di dalamnya. Arkeologi dikatakan pula sebagai sebuah ilmu multidisipliner karena di dalam upaya menjelaskan dan memahami persoalan sejarah kebudayaan, cara-cara hidup, perilaku manusia dan perubahan budaya di masa lampau sangat diperlukan penggunaan perspektif atau kerangka pikir ilmu lain.

Lanskap merupakan salah satu pendekatan 'tematik' yang diserap dari perspektif dan kerangka pikir ilmu lain untuk menyelesaikan persoalan-persoalan arkeologi. Penggunaan pendekatan lanskap dalam menyelesaikan persoalanpersoalan arkeologi berkembang menjadi salah satu bidang kajian yang khusus yang disebut dengan istilah arkeologi lanskap.

$$
\text { Kemunculan arkeologi }
$$

lanskap sendiri tidak bisa dilepaskan dari perkembangan pemikiran mengenai ilmu arkeologi. Pada mulanya, kajian lanskap lahir dari semangat pemikiran prosesual yang dimulai dari penggunaan metode ilmiah sebagaimana yang berkembang dalam ilmu-ilmu alam untuk menjelaskan proses budaya di masa lalu dan terus berkembang pada era pasca-prosesual (Webster, 2009:11-12).

Pemikiran pasca-prosesual yang lahir sekitar tahun 1980-an, muncul sebagai kritik terhadap pemikiran prosesual. Salah satu kritik tersebut misalnya pandangan bahwa budaya materi merupakan hasil dari proses adaptif jangka panjang dan alat untuk merespon lingkungan (Hodder, 2005:155-156). Artinya, budaya materi tidak semata-mata ciptaan manusia tetapi sebagai hasil proses adaptasi manusia terhadap lingkungan. Sebaliknya, pascaprosesual menganggap bahwa budaya materi bersifat aktif. Artinya, budaya materi diciptakan, digunakan dan dimanipulasi oleh manusia untuk memicu terjadinya perubahan sosial (Hodder, 2005: 156).

Lebih jauh dalam tulisannya yang lain, Hodder menyatakan budaya materi sesungguhnya merupakan benda buatan individu yang melaluinya, individu tersebut hendak menyampaikan sesuatu dan untuk mengungkap pesan dan makna dari budaya materi tersebut diperlukan proses interpretasi (Hodder dan Hutson, 2003: 6). Oleh sebab itu, pemikiran pasca-prosesual cenderung intepretatif dan bersifat partikularistik (khusus) serta tidak bisa menghasilkan dalil-dalil umum (Hodder, 1991: 71-78).

Adanya paradigma prosesual dan pasca-prosesual berpengaruh secara langsung terhadap kajian lanskap. Dua paradigma yang saling bertentangan ini, memiliki pemahaman yang berbeda mengenai 
arkeologi lanskap. Hal ini seringkali menimbulkan ambiguitas dalam memahami lanskap itu sendiri (Gosden dan Head, 1994: 15). Di sisi lain, juga menimbulkan kekeliruan dalam menempatkan posisi arkeologi lanskap dengan kajian arkeologi lain, misalnya dengan arkeologi lingkungan, arkeologi spasial, dan arkeologi permukiman.

Untuk memahami lebih jauh perbedaan pemahaman antara arkeologi lanskap baik dari perspektif prosesual maupun pasca-prosesual maka dalam tulisan ini akan dibahas tentang bagaimana dua perspektif ini melihat lanskap situs-situs megalitik di Dataran Tinggi Jambi. Situs-situs megalitik ini pertama kali dilaporkan oleh G.H.K de Bont (1922), dan penelitian selanjutnya dilakukan oleh F.M. Schnitger (1936), Bagyo Prasetyo (1994), Dominik Bonatz (2003, 2005, 2006, 2009) dan T.M.S Budisantosa $(2006,2015)$ (lihat Aziz, 2010).

Sebagaimana yang telah dipaparkan bahwa pemahaman tentang arkeologi lanskap dalam perspektif prosesual dan pascaprosesual memiliki banyak perbedaan, maka permasalahan yang muncul adalah apa saja ciri-ciri perbedaan di antara keduanya? Bagaimana hasil yang diperoleh dari dua perspektif paradigma ini dalam melihat lanskap arkeologi situs megalitik di Dataran Tinggi Jambi?

Tujuan penulisan artikel ini adalah: (1) untuk mengetahui ciri-ciri perbedaan antara arkeologi lanskap dalam perspektif paradigma prosesual dan pasca-prosesual; dan (2) untuk mengetahui perbedaan hasil yang dicapai dari dua perspektif tersebut dalam melihat lanskap situs megalitik di Dataran Tinggi Jambi.

\section{METODE}

Penelitian ini dimulai dari pengumpulan data yang diperoleh melalui studi kepustakaan. Data tersebut terkait dengan megalitik di Dataran Tinggi Jambi, kajian lanskap dalam arkeologi dan perkembangan paradigma dalam ilmu arkeologi. Data tersebut kemudian dianalisis secara deskriptif melalui penalaran induktif. Selanjutnya, dilakukan interpretasi terhadap hasil analisis yang diperoleh. Interpretasi tersebut terkait dengan megalitik di Dataran Tinggi Jambi dan implementasinya dalam kajian lanskap berdasarkan kerangka paradigma prosesual dan pasca-prosesual.

\section{HASIL PENELITIAN}

\section{Lanskap dalam Perspektif Prosesual}

Arkeologi prosesual atau disebut pula dengan arkeologi pembaharuan pada dasarnya muncul sebagai ketidakpuasan terhadap pemikiran arkeologi sebelumnya yaitu arkeologi tradisional. Paradigma arkeologi tradisonal pada hakikatnya hanya memberikan deskripsi untuk merekonstruksi kehidupan masa lampau dan hanya melihat budaya secara normatif. Fokus kajiannya untuk menempatkan materi arkeologi pada konteks ruang dan waktu melalui analisis yang berhati-hati dan klasifikasi artefak yang diperoleh dari hasil ekskavasi. Pada masa ini, arkeolog mampu menempatkan objek-objek arkeologi dalam urutan kronologi, memetakan distribusinya dalam suatu kawasan, dan mengelompokkan materi dalam budaya-budaya dengan batas-batas spasial dan temporal yang jelas (Sabloff, 2005: 159).

Akan tetapi kemudian, cara kerja tradisionalis ini dikritik oleh para 
arkeolog lain. Walter W. Taylor pada tahun 1940-an mengkritik kaum tradisionalis dengan menyatakan bahwa para peneliti seharusnya melakukan analisis terhadap material yang ditemukannya guna menemukan fungsi dari material yang dikajinya itu, bukan hanya menempatkan mereka pada konteks waktu dan spasial (Sabloff, 2005: 160). Kemudian, Lewis Binford juga mengkritik para tradisionalis dengan pernyataannya bahwa para ahli arkeologi seharusnya melihat eksplanasi sebagai tujuan mereka bukan sebagai deskripsi. Eksplanasi arkeologi bukan sekadar spekulasispekulasi tetapi harus didukung secara jelas oleh pemahaman terhadap rekaman arkeologi, pertanyannya bukan lagi kapan, apa, dan dimana tetapi lebih jauh lagi yaitu tentang 'mengapa' dan 'bagaimana' (Sabloff, 2005: 160).

Binford (dalam Greene, 2003: 170) menyatakan bahwa:

"....it is only through explanations of our observations that we gain any knowledge of the past. Explanation begins for the archaeologist when observations made of the archaeological record are linked through laws of cultural or behavioral functioning to past conditions or events..".

Menurutnya, hanya melalui eksplanasi yang diperoleh dari observasi, berbagai pengetahuan tentang masa lalu dapat diperoleh. Eksplanasi itu dimulai saat pengamatan rekaman arkeologis yang dihubungkan dengan teori kebudayaan atau perilaku untuk merumuskan kondisi atau kejadian masa lalu.

Serangkaian kritik dan $\begin{array}{ll}\text { penolakan } & \text { Binford terhadap } \\ \text { paradigma tradisional tersebut }\end{array}$ melahirkan paradigma arkeologi baru yang disebut dengan arkeologi pembaharuan atau arkeologi prosesual. Selanjutnya, Binford menyusun beberapa kata kunci penting dalam paradigma prosesual (Sabloff, 2005: 160-161).

Pertama, budaya dilihat sebagai sebuah sistem dengan aspek teknologi, ekonomi, politik dan ideologi yang saling terkait satu sama lain. Kedua, menekankan pentingnya ekologi kultural, dan perlunya untuk melihat interaksi lingkungan dan budaya secara sistemik terutama hubungan antara lingkungan dan teknologi. Ketiga, Binford berargumen bahwa arkeolog harus mempelajari evolusi sistem budaya sepanjang waktu untuk menghasilkan narasi umum (general narrative). Kaum prosesualis sangat menekankan pengkajian terhadap perubahan budaya. Mereka juga berusaha menjelaskan persamaan dan perbedaan budaya sebagai pusat perhatiannya untuk mendapatkan dalil umum. Oleh karenanya, kajiannya bersifat materialistik dan lebih cenderung mengarah ke bidang sains dengan metode deduktif. Pokok dari metodologi arkeologi harus menjadi hipotesis yang teruji (Greene, 2003: 170; Wylie: 72-74). Lebih lanjut Alison Wylie (2002: 78) menyebutkan bahwa paham prosesual sangat mendukung positivisme dan empirisme. Positivisme adalah keyakinan bahwa argumen dibangun oleh pengujian teori dengan data yang objektif dan mandiri (Hodder, 2005: 155).

Pandangan prosesual yang menganggap budaya sebagai sebuah sistem yang terdiri dari interaksi antar subsistem, menekankan adanya variabilitas 
(perbedaan) kebudayaan daripada homogenitas atau persamaannya. Hal ini berdampak besar pada kegiatan arkeologis yang dilakukan. Pengumpulan dan perekaman data secara menyeluruh pada suatu situs tidak serta merta dapat mengungkapkan seluruh aspekaspek kebudayaan melainkan hanya aspek-aspek kecil dari satu subsistem budaya saja. Untuk itu, diperlukan strategi dan metode yang baik dalam pengambilan sampel sehingga dari sampel tersebut arkeolog mampu menarik kesimpulan yang meyakinkan tentang sistem kebudayaan masa lalu secara menyeluruh berdasarkan pengetahuan parsial mereka (Sabloff, 2005: 161).

Prosesualis juga menganggap bahwa kebudayaan bersifat pasif. Maksudnya adalah ideologi dan perilaku manusia maupun budaya materi yang diciptakannya dibentuk oleh lingkungan alam dan sosial (Hodder, 2005: 156). Sebagai contoh, perahu dibuat oleh manusia yang umumnya tinggal di kawasan sungai-sungai besar, danau dan pesisir pantai dengan tujuan untuk memudahkan mobilitas mereka. Perahu dan alat transportasi air lainnya tidak akan dibuat oleh manusia yang hidup di gurun dan sabana.

Pandangan prosesualis terhadap hubungan antara budaya material dan perilaku manusia dengan lingkungannya berimplikasi pada pemahaman mereka terhadap lanskap. Lanskap diartikan sebagai bentang alam dari suatu wilayah yang merupakan bagian dari berbagai komponen baik alam maupun binaan (Lihat. Gosden dan Head, 1994; Tanudirjo, 2017). Johnson (2007) menyebutkan bahwa lanskap adalah bentangalam itu sendiri yang fitur-fiturnya diciptakan oleh manusia dan secara objektif masih bisa diamati dalam konteks alaminya.

Lanskap dalam pandangan mereka adalah entitas yang terdiri dari unsur-unsur fisik semata. Keberadannya bukan hal yang abstrak tetapi benar-benar bisa diamati dalam konteksnya. Unsur fisik tersebut berupa fitur-fitur yang terbentuk secara alamiah maupun yang dimodifikasi dan dibentuk oleh manusia.

Oleh karena paradigma prosesual yang bersifat materialistik ini, maka kajian tentang lanskap-pun akan lebih ditekankan pada unsurunsur fisik baik alami maupun buatan seperti gunung, bekas pertambangan, danau, sungai, candi, situs megalitik dan lain sebagainya. Daud A. Tanudirjo (2017) dalam presentasinya memaparkan bahwa kajian lanskap dalam paradigma prosesual akan fokus membahas di antaranya tentang: (1) unsur-unsur alam dan budaya, (2) hubungan antar unsur, (3) pengaruh unsur alam terhadap budaya, dan (4) menjelaskan hubungan antar unsur alam dan pengaruh budaya. Maka dari itu kajian lanskap dalam paradigma prosesual melahirkan berbagai jenis kajian arkeologi seperti arkeologi spasial, arkeologi lingkungan, arkeologi permukiman, arkeologi demografi dan arkeologi regional.

\section{Lanskap dalam Perspektif Pasca- prosesual}

Sama halnya dengan paradigma arkeologi tradisional, paradigma prosesual-pun pada akhirnya tidak luput dari berbagai kritikan. Ialah lan Hodder bersama koleganya yang melontarkan pemikiran oposisional bagi para prosesualis di tahun 1980-an. 
lan Hodder (2005) dalam

tulisannya 'Post-Processual and Interpretive Archaeology' telah memaparkan serangkaian kritik yang dilontarkan terhadap arkeologi prosesual. Pertama, prosesual mementingkan teknologi adaptif, dengan merangkul antropologi lintas budaya, dan mengabaikan konteks sejarahnya, Prosesual juga sangat positivis karena meyakini adanya kebenaran tunggal.

Kedua, arkeologi prosesual memisahkan antara budaya materi dengan aspek simbolisnya, dengan kata lain mengabaikan simbolisme suatu budaya materi atau mengabaikan kebermaknaannya. Ketiga, budaya materi dalam paradigma prosesual merupakan hal yang pasif, di mana suatu alat dibuat sebagai respon terhadap lingkungan. Terakhir, arkeologi prosesual menggunakan metode deduktif yang cenderung melakukan generalisasi lintas budaya (lihat pula Wylie, 2002: 115-161).

Sebagai penolakan terhadap pandangan prosesualis, sekitar tahun 1980-an lan Hodder bersama koleganya melaksanakan konferensi di Universitas Cambridge dan hasil konferensi itu kemudian dibukukan dalam sebuah karya yang berjudul ' Structural and Symbolic Archaeology'. Melalui konferensi tersebut lan Hodder merumuskan dan menawarkan pemikiran baru dalam dunia arkeologi, yang pada akhirnya kerangka pikir tersebut disebut dengan paradigma arkeologi pascaprosesual.

Di antara poin penting pemikiran pasca-prosesual adalah: (1) menolak pandangan bahwa budaya sebagai sistem atau struktur, (2) adanya peran individu dalam membentuk kebudayaan, kegiatan penafsiran dalam arkeologi sangat erat kaitannya dengan subjektivitas penafsir. Oleh sebab itu, tidak ada hal yang bersifat murni objektif, (4) konteks dari kebudayaan materi sangat penting dan menentukan hasil penafsiran, (5) pengetahuan bersifat interpretatif dan khusus, sehingga menolak adanya generalisasi dan kebenaran tunggal, (6) adanya politik di balik ilmu, (7) pengetahuan masa lampau diperoleh dan dipakai untuk merekonstruksi masa kini, (8) membuka kesempatan untuk beragam penafsiran, (9) sangat memperhatikan makna dari budaya materi, (10) menggunakan metode induktif-deduktif (11) hermeneutika sebagai metode interpretasi (lihat Hodder, 2005: 155-158; Hodder dan Hutson, 2003: 236-235).

Berdasarkan paparan di atas, tampak bahwa pasca-prosesual menekankan proses interpretasi dalam memahami budaya materi. Hal ini ditegaskan oleh Hodder (2005: 156-157) dalam tulisannya:

"The emphasis on interpretation (rather than the processual emphasis on explanation) is that different people with different social interests will construct the past differently".

Oleh sebab itu, pasca-prosesual tidak mempermasalahkan subjektivitas karena pada dasarnya interpretasi seseorang tidak bisa dilepaskan dari subjektivitasnya. Menurut paham ini tidak ada kebenaran tunggal sehingga setiap orang dapat menafsirkan budaya materi dari perspektif masingmasing.

Lebih lanjut, pasca-prosesual menekankan bahwa kebudayaan tidak hanya hasil cipta manusia akibat dibentuk oleh lingkungan alam dan sosial, tetapi lebih dari itu, bahwa 
kebudayaan merupakan hasil pemikiran (gagasan/ ideologi) manusia. Oleh karena itu, adanya perbedaan perilaku dan hasil budaya ditentukan oleh individu itu sendiri sebagai pelaku yang berperan dalam proses kebudayaan. Misalnya saja mengapa suku Inca memilih membangun Machu Picchu di pegunungan setinggi $2350 \mathrm{mdpl}$ dibanding di kawasan lembah? Apakah area puncak gunung itu secara ekonomi dan sosial lebih baik dan menguntungkan dari kawasan lembah? Ataukah pemilihan lokasi Machu Picchu dilatarbelakangi oleh konsep atau gagasan tertentu?

Berangkat dari akar pemikiran ini, pasca-prosesualis menganggap bahwa lanskap bukan semata-mata dibentuk dari hubungan manusia dengan lingkungannya. Akan tetapi merupakan hasil pikir dan tindakan manusia itu sendiri. Oleh sebab itu, kajian lanskap dalam perspektif pasca-prosesual fokus pada tataran gagasan manusia sebagai pencipta lanskap bukan sekadar melihat dan menjelaskan hubungan unsur-unsur fisiknya semata. Hal ini terlihat pula dari bagaimana kaum pascaprosesualis mendefinisikan dan mengartikan lanskap.

Berbeda dengan para prosesualis yang menyebut lanskap sebagai bentangalam yang terdiri dari unsur fisik dan buatan, pascaprosesualis mendefinisikan lanskap di antaranya: (1) lanskap sebagai 'konstruksi pikiran' (Tuan dalam Johnson, 2007: 3); (2) lanskap sebagai konstruksi visual (Porteous dalam Johnson, 2007: 3); (3) lanskap adalah bagaimana 'daratan' (the land) dilihat, bagaimana kita dan orang-orang di masa lampau memandang dan memahami lanskap, dan apa sistem pemaknaan dan pemahaman lanskap mereka, sistem kognitif dan proses-proses persepsi (Johnson, 2007: 4), (4) semua lanskap dikonstruksi oleh manusia baik melalui aktivitas fisik (membangun sesuatu, melaksanakan, ritual tertentu) maupun melalui mitologi; lanskap tergantung dari interpretasi orang-orang yang tinggal di dalamnya (Layton dan Ucko, 1994) (5) lanskap tidak sama dengan lingkungan alam. Lanskap merupakan buatan (sintetik), dengan struktur sistem budaya dan interaksi organisai manusia dengan lingkungannya (Anchuets et. al , 2001: 160); (6) ide atau konsep paling mutakhir tentang lanskap menekankan pada dimensi sosiosimbolik, bahwa lanskap merupakan entitas yang ada karena dikenali, dirasakan dan dikonseptualisasikan oleh masyarakat pendukungnya (Ashmore dan Knapp, 1999). Oleh sebab itu, menurut Tanudirjo (2017) kajian lanskap dalam perspektif pasca-prosesual akan fokus membahas tentang: (1) unsur apa yang dipilih individu/ kelompok manusia, (2) sudut pandang (perspektif) yang diambil individu/ kelompok, (3) alasan individu/ kelompok manusia memilih unsur dan sudut pandang itu, (4) memahami gambar dari sudut pandang pelukis/memahami lanskap dari sudut pandang Si Pembuat (makna dan konteks). Di sisi lain, pandangan pasca-prosesual juga menuai kritik, Kritik tersebut ditujukan dalam hal persamaan hasil kesimpulan interpretatif yang diperoleh oleh arkeolog terhadap suatu objek arkeologis dengan manusia yang menciptakan objek arkeologis di masa lalu. Padahal secara epistemologis tidak ada dua kebudayaan yang sama persis. Oleh sebab itu, Hodder menambahkan unsur fenomenologi dalam proses interpretasi. 
Fenomenologi menekankan adanya hubungan timbal balik antara subjek dengan objek yang diteliti misalnya, antara peneliti atau arkeolog dengan objek arkeologi yang ditelitinya. Fenomenologi memfokuskan tentang cara seseorang memperoleh pengalaman dari berinteraksi dengan objek (dalam hal ini objek arkeologis) melalui pengindraan tubuhnya selama melakukan interpretasi (Tilley, 2005: 151). Menurut Tilley, fenomenologi memandang bahwa semua manusia modern (Homo sapiens sapiens) memiliki bentuk tubuh yang sama dan mereka memiliki cara yang sama dalam merasakan dan mengalami dunia pada tingkat biologi dasar (Tilley, 2005: 152). Dengan demikian, apa yang dirasakan dan dialami oleh manusia masa lalu maupun masa kini terhadap sebuah objek akan memiliki persamaan karena mereka menggunakan indra tubuh yang serupa. Oleh sebab itu di dalam fenomenologi, penggunaan indra tubuh lebih diutamakan selama proses interpretasi dibandingkan dengan penggunaan alat-alat canggih.

\section{DISKUSI DAN PEMBAHASAN}

\section{Lanskap Megalitik di Dataran Tinggi Jambi dalam dua Paradigma}

Gosden dan Head (1994) mengatakan bahwa lanskap sebagai 'konsep ambigu'. Hal ini karena lanskap seringkali susah dipahami dan tidak ada batasan yang jelas mengenai ruang lingkup kajiannya. Ada tumpang tindih baik antara kajian lanskap dengan kajian lain di dalam arkeologi maupun antara konsep lanskap di dalam arkeologi dengan konsep lanskap dalam bidang kajian ilmu lain. Sejatinya, ambiguitas lanskap di dalam kajian arkeologi terjadi karena tidak dipisahkannya pengertian lanskap dalam perspektif paradigma prosesual dan pasca-prosesual. Untuk itu, dalam bagian ini akan dibahas mengenai bagaimana lanskap megalitik di Dataran Tinggi Jambi, dilihat dari sudut pandang dua paradigma ini. Megalitik di Dataran Tinggi Jambi (meliputi wilayah Kerinci dan Merangin) memiliki karakteristik yang khas dibandingkan dengan megalitik lainnya yang ada di Indonesia (Aziz, 2012: 654). Megalitik ini merupakan batu monolit yang berbentuk silinder atau kerucut yang diposisikan secara horizontal (rebah). Umumnya, pada permukaan megalitik memiliki pola hias lingkaran konsentrik, setengah lingkaran, figur manusia, antropomorfik, dan sulursuluran (Bonatz dkk., 2006: 505-507) (lihat gambar 1).

Hingga kini, ditemukan sebanyak 22 megalitik yang berbentuk silindris dan kerucut dengan persebaran yaitu, 10 megalitik di Kerinci, enam megalitik di Pratin Tuo, tiga megalitik berada di Serampas, dan tiga megalitik berada di Sungai Tenang (lihat gambar 2). Hasil pertanggalan yang diperoleh di sekitar situs maupun pertanggalan dari situs penguburan tempayan yang letaknya tidak jauh dari megalitik menunjukkan umur megalitik di Kerinci berada di sekitar abad ke-8 hingga abad ke-14 M (Tjoa-Bonatz, 2009: 24).

Dalam perspektif prosesual, lanskap megalitik Dataran Tinggi Jambi diteliti dengan mencari hubungan antar unsur-unsur fisik seperti asosiasi megalit dengan 


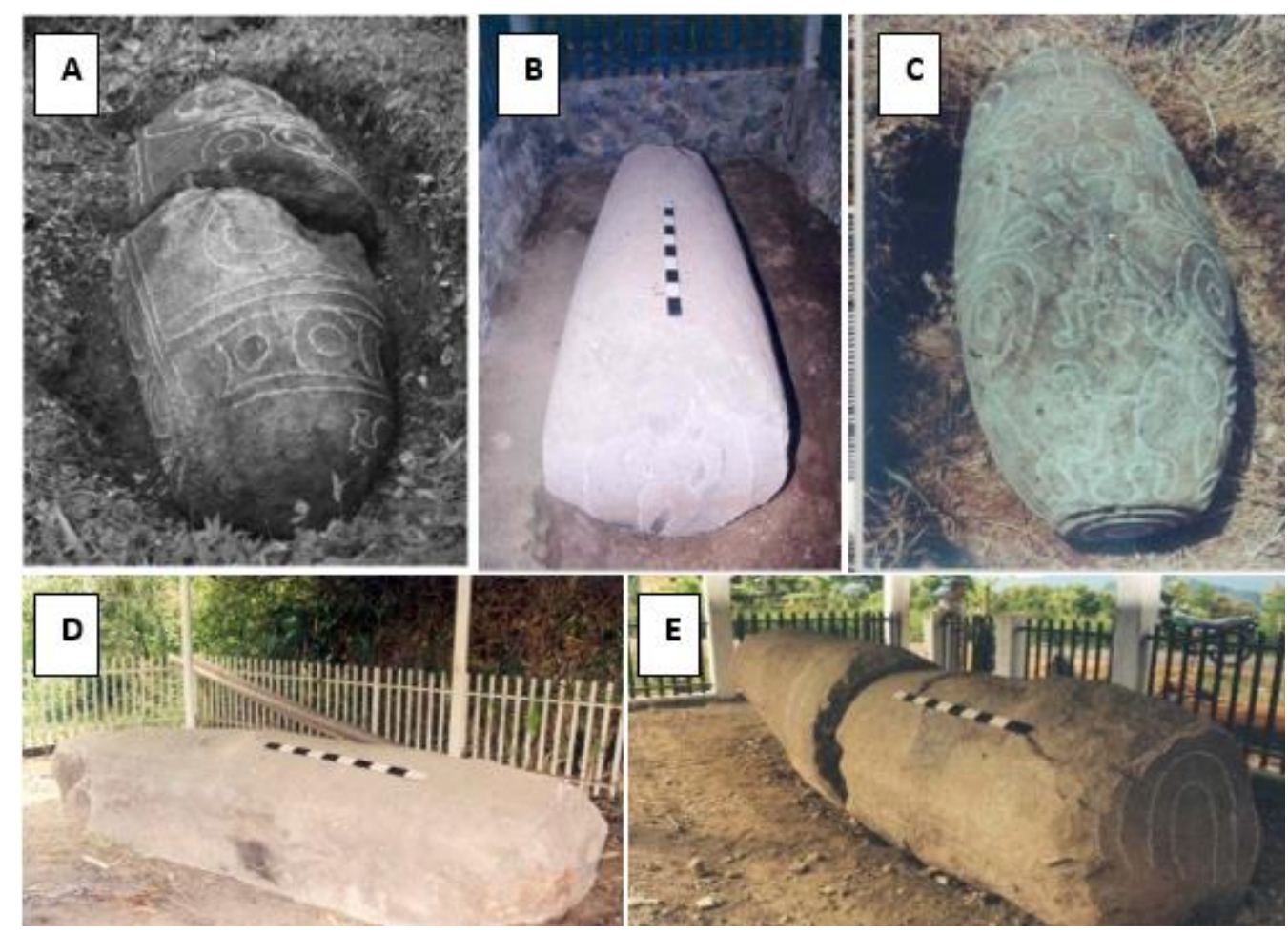

Gambar 1. Situs-situs megalitik di Kerinci (A) Situs Pulau Sangkar I (B) Situs Benik (C) Situs Pondok (D) Situs Pulau Sangkar II (E) Situs Batu Patah Muak (Sumber: Tjoa-Bonatz: 2009; Dok. Disparbud Kerinci, 2008)

gunung atau bukit di sekitarnya, hubungan keletakan megalitik dengan sisa permukiman kuna yang sezaman, dan asosiasi megalitik dengan variabel ketinggian lahan dan asosiasi megalitik dengan kubur tempayan serta orientasi megalitik ke arah tertentu. Hasil penelitian terdahulu menunjukkan bahwa lanskap megalitik di Dataran Tinggi Jambi dijelaskan dalam paradigma prosesual di antaranya: pertama, sebagian besar megalitik berada di dataran yang lebih tinggi seperti di puncak bukit dan sisi lereng bukit, hanya ada tiga megalitik yang berada di wilayah lembah (Bonatz dkk., 2006: 504). Kedua, semua megalitik berorientasi mengarah ke gunung atau bukit yang ada di sekitarnya. Oleh sebab itu, megalitik disebut sebagai simbol pemujaan kekuatan supernatural yang berada di Gunung
(Bonatz dkk., 2006: 504; Budisantosa: 2015: 22; lihat tabel 1). Ketiga, megalitik berada dekat dengan konteks permukiman kuna sezaman, dibuktikan dari hasil ekskavasi sekitar megalitik (Bonatz dkk., 2006: 504). Keempat, megalitik berasosiasi dengan kubur tempayan (Budisantosa, 2015: 27).

Hasil yang dicapai oleh prosesualis dalam menjelaskan tentang lanskap situs megalitik ini, hanya mampu memberikan penjelasan umum saja seperti empat poin di atas. Akan tetapi, tidak bisa menjelaskan mengenai hal-hal yang bersifat khusus misalnya mengapa tiga megalitik justru ditempatkan di wilayah lembah, dan tidak di dataran yang lebih tinggi sebagaimana 16 megalitik lainnya. Padahal, ciri-ciri megalitiknya sama dan lingkungannya pun tidak jauh berbeda. Selain 


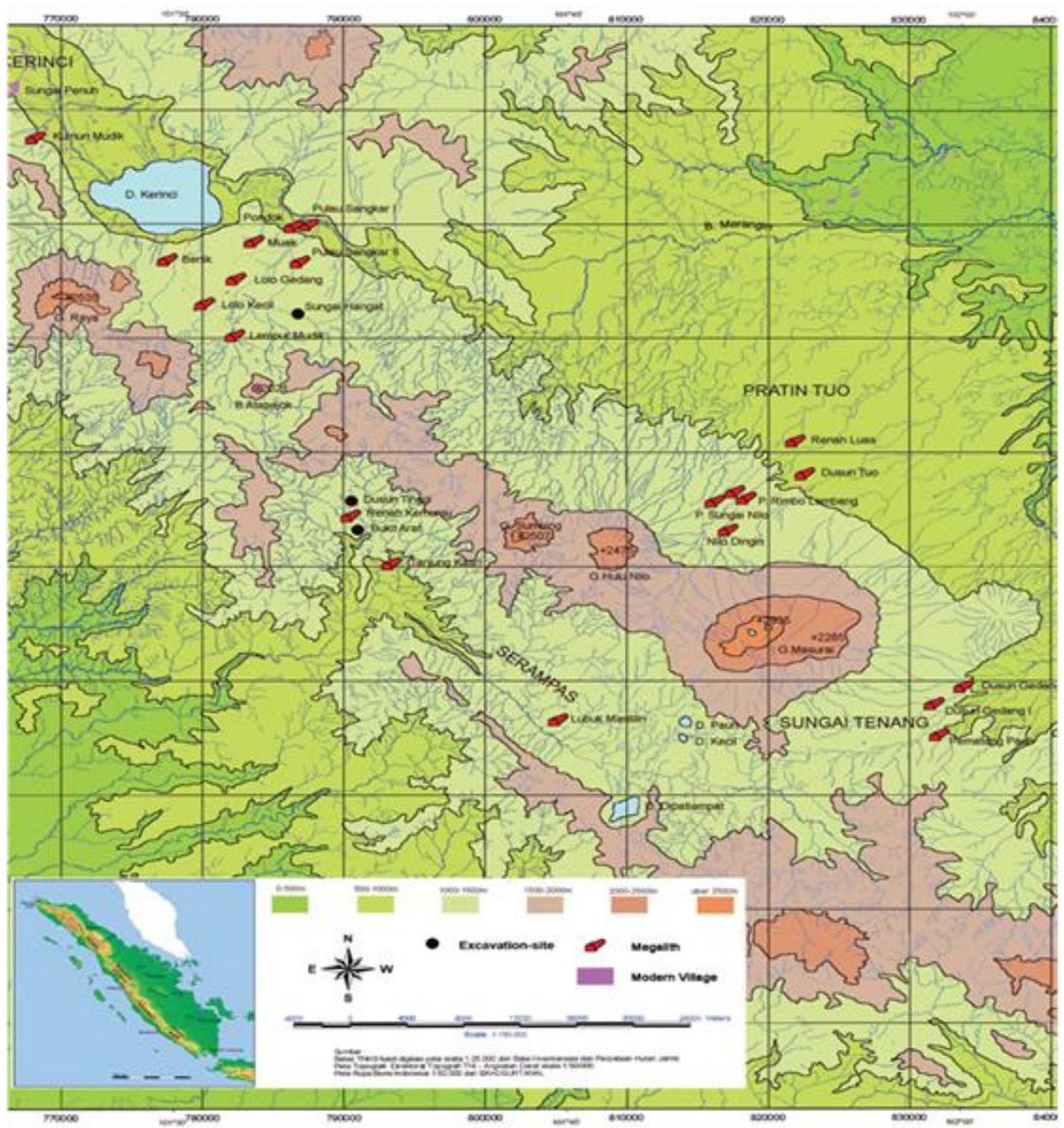

Gambar 2. Sebaran Situs-situs megalitik berbentuk silindrik dan kerucut di Dataran Tinggi Jambi

(Sumber: Bonatz, 2012: 39)

itu, tidak dapat pula dijelaskan mengapa megalitik berorientasi pada bukit atau gunung yang paling dekat di sekitarnya, dan tidak mengarah hanya ke satu gunung saja seperti ke Gunung Kerinci yang merupakan gunung tertinggi di Sumatra, atau ke Gunung Masurai yang merupakan gunung tertinggi di wilayah Merangin. Padahal, dalam tataran kosmologis justru gunung yang lebih tinggi memiliki kekuatan supernatural yang lebih dibandingkan dengan gunung yang lain karena dianggap sebagai tempat persemayaman arwah leluhur.

Di sisi lain berdasarkan perspektif pasca-prosesual, megalitik di Dataran Tinggi Jambi diteliti dengan melihat persepsi masyarakat terhadap megalitik yang ada di sekitar mereka. Sebagaimana yang telah diungkapkan oleh Budisantosa (2015: 23) dan Bonatz dkk. (2006: 509-510) bahwa ada dua persepsi 


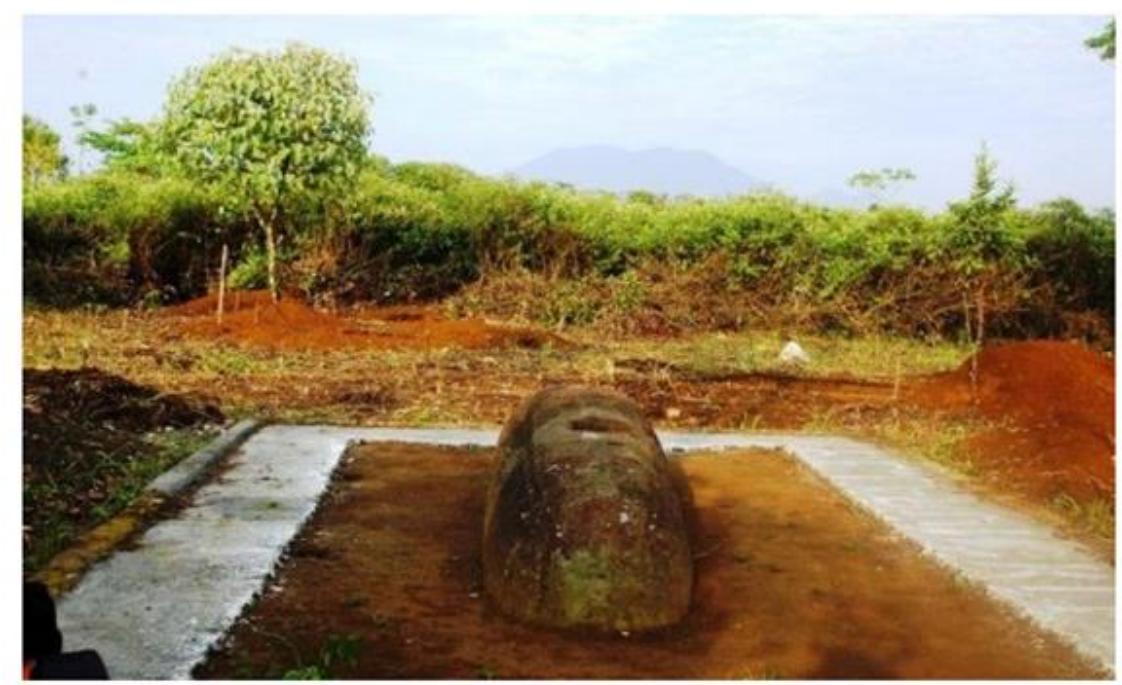

Gambar. 3. Megalitik di Dusun Tuo menghadap Gunung Hulu Nilo (Sumber: Budisantosa, 2015)

Tabel 1. Data Orientasi Beberapa Megalitik Dataran Tinggi Jambi

\begin{tabular}{llll}
\hline No & Situs Megalitik & $\begin{array}{l}\text { Orientasi } \\
\text { Mata Angin }\end{array}$ & Orientasi Khitonis \\
\hline $\mathbf{1}$ & Kumun Mudik & $30^{\circ} \mathrm{U}$ & Bukit Adam \\
$\mathbf{2}$ & Tanjung Batu & $320^{\circ} \mathrm{U}$ & Gunung Kerinci \\
$\mathbf{3}$ & Batu Patah Muak & $340^{\circ} \mathrm{U}$ & Gunung Kerinci \\
$\mathbf{4}$ & Lolo Gedang & $210^{\circ} \mathrm{U}$ & Gunung Kunyit/Gunung Raya \\
$\mathbf{5}$ & Lempur & $190^{\circ} \mathrm{U}$ & Gunung Kunyit \\
$\mathbf{6}$ & Pulau Sangkar & $330^{\circ} \mathrm{U}$ & Gunung Kerinci \\
$\mathbf{7}$ & Dusun Tuo & $244^{\circ} \mathrm{U}$ & Gunung Hulu Nilo \\
$\mathbf{8}$ & Pematang Sungai Nilo & $250^{\circ} \mathrm{U}$ & Gunung Hulu Nilo \\
$\mathbf{9}$ & Nilo Dingin (Tanjung Putih) & $295^{\circ} \mathrm{U}$ & Gunung Sumbing \\
$\mathbf{1 0}$ & Talang Jambu Abang & $20^{\circ} \mathrm{U}$ & Gunung Sumbing \\
$\mathbf{1 1}$ & Bukit Batu Larung & Baratlaut & Gunung Gerakah \\
\hline
\end{tabular}

Sumber: Budisantosa, 2015: 22

Pertama, batu megalitik dikatakan dari peperangan antara dua nenek moyang yang bersemayam di dua gunung berbeda seperti kasus situs megalitik Lempur dan megalitik Dusun Tuo. Masyarakat Lempur menganggap bahwa batu silindris tersebut merupakan peluru batu yang dilontarkan ketika terjadi peperangan antar nenek moyang yang dalam peperangan tersebut menyebabkan puncak Gunung Kerinci pecah (Bonatz dkk. 2006: 509). Sama halnya dengan yang terjadi di Dusun Gedang mereka menganggap bahwa megalitik di desa mereka sebagai peluru batu yang dilontarkan ketika terjadi peperangan antara leluhur yang bernama Nenek Mantring Baju 
Temago yang bersemayam di Gunung Sumbing dan Nenek Serampu Alam Sati yang bersemayam di Gunung Gerakah (Budisantosa, 2015: 22-23).

Kedua, dua buah megalitik di Dusun Gedang yang dinamakan sebagai batu larung jantan dan batu larung betino dinarasikan wujud dari seorang pria dan wanita yang terkena kutukan tokoh mitologi 'Si Pahit Lidah' akibat melanggar larangan adat (Bonatz dkk., 2006: 510). Berdasarkan pandangan pascaprosesual, lanskap dapat dimaknai beraneka ragam tergantung pada siapa, waktu, tempat dan suasana yang dipilih. Seperti pada kasus megalitik di Dataran Tinggi Jambi, ternyata terdapat berbagai persepsi di tengah masyarakat mengenai keberadaan megalitik di sekitar mereka. Hal yang menarik adalah tema yang berkembang dalam legenda dibalik megalitik tersebut berkenaan dengan perang, nenek moyang, dan gunung. Legendalegenda ini memiliki relasi dengan orientasi megalitik yang juga menghadap ke arah gunung tertentu. Oleh sebab itu, mungkin saja ada 'makna tersembunyi' yang berelasi dengan aksi dibalik penempatan megalitik, perbedaan-perbedaan lokasi penempatan megalitik ataupun perbedaan arah orientasi megalitik.

Sebagai contoh, mengapa orientasi megalitik menghadap ke arah gunung yang berbeda, bukannya ke arah gunung yang paling tinggi. Di sini kita bisa mempertimbangkan keterjangkauan visual manusia menggunakan fenomenologi, seperti sejauh mana gunung tertentu dapat dilihat dari lokasi megalitik. Berdasarkan pengamatan tersebut akan terlihat adanya "lokalitas" yang dimiliki oleh masing-masing megalitik. Artinya, tiap-tiap megalitik menghadirkan suasana dan kesan yang berbeda dalam relasinya dengan lanskap.

Legenda tentang "perang gunung" yang mengiringi megalitik sangat menarik, mengapa tema perang dipilih untuk menarasikan keberadaan megalitik pada suatu tempat? Legenda tentang perang umumnya muncul pada suku-suku yang sering berkonflik dan berperang pada suatu kawasan. Konflik tersebut biasanya dilatarbelakangi oleh perebutan hak untuk menguasai lahan dan sumber daya alam tertentu pada suatu kawasan. Oleh sebab itu, mungkin saja megalitik tersebut sebagai penanda wilayah adat/ kekuasaan antarsuku di masa lalu yang mendiami Dataran Tinggi Jambi. Masing-masing suku memiliki keyakinan dan kepercayaan yang berbeda terhadap gunung-gunung yang dianggap suci. Oleh sebab itu, megalitik diarahkan pada gununggunung yang berbeda pula. Dengan demikian, dapat dikatakan bahwa megalitik tidak hanya sebagai simbol sakral semata. Akan tetapi, juga sebagai identitas-identitas suku yang membuatnya di masa lalu.

Kasus lain misalnya megalitik di Dusun Gedang, diceritakan bahwa keberadaan megalitik tersebut merupakan wujud dari sepasang manusia yang berubah menjadi batu akibat disumpah (dikutuk) oleh $\mathrm{Si}$ Pahit Lidah. Mereka dikutuk Lidah karena melanggar pantangan adat tertentu. Legenda tentang Si Pahit Lidah yang kutukannya mampu mengubah manusia dan hewan menjadi batu juga berkembang Pasemah, Sumatra Selatan. Masyarakat percaya bahwa megalitik yang ada di sana merupakan hasil kutukan dari leluhur mereka yang 
bernama Si Pahit Lidah atau dikenal pula sebagai Serunting Sakti (Guillaud dkk., 2009: 429).

Legenda Si Pahit Lidah yang memiliki kekuatan mengutuk manusia menjadi batu memanglah legenda yang sangat dikenal oleh masyarakat yang mendiami Sumatra Bagian Selatan (Jambi, Bengkulu dan Sumatra Selatan) sebagaimana yang telah diungkap dalam penelitian sebelumnya. Barangkali, legenda tersebut sama sekali tidak terkait dengan komunitas awal yang mendirikan megalitik. Akan tetapi, diberi makna yang berbeda oleh komunitas lain yang datang ke tempat tersebut pada periode berikutnya atau oleh generasi yang lahir setelahnya. Hal ini berkaitan erat dengan kepentingan politis yang mendominasi di Sumatra bagian Selatan pada periode sejarah tertentu.

Narasi terhadap megalitik sebagai wujud dari manusia yang dikutuk akibat melanggar aturan adat, dibuat dengan tujuan untuk 'menakuti' penduduk di sekitarnya agar senantiasa menaati aturanaturan adat yang dibuat oleh penguasa atau yang disepakati bersama oleh masyarakat pada periode waktu tertentu. Dengan demikian, tidak dapat dipungkiri ada perubahan (transformasi) makna terhadap megalitik dari masa ke masa.

Serangkaian pandanganpandangan di atas, dimunculkan untuk menggambarkan bahwa melalui perspektif pasca-prosesual kita dapat menggali lebih dalam tinggalan arkeologis dalam relasinya dengan lanskap. Satu tinggalan saja dapat dideskripsikan secara mendalam karena tiap-tiap tinggalan tersebut memiliki ciri khusus masingmasing. Terlebih lagi, masing-masing individu dan kelompok memiliki persepsi yang berbeda terhadap tinggalan megalitik dan lanskap di sekitar mereka. Paradigma pascaprosesual bersifat lebih humanistik dan memberikan ruang multitafsir terhadap lanskap beserta tinggalantinggalan arkeologis di dalamnya.

\section{KESIMPULAN}

Pemahaman lanskap dalam perspektif paradigma prosesual dan pasca-prosesual ternyata cukup berbeda. Lanskap dalam perspektif prosesual lebih menekankan kajian pada unsur fisik untuk menjelaskan lanskap alam maupun lanskap budaya. Selain itu, kajian lanskap dalam perspektif ini hanya mampu memberikan suatu penjelasan yang umum terhadap permasalahan yang dikajinya berdasarkan observasi dan rekaman arkeologis yang di dapatkan.

Dalam kasus kompleks megalitik di Dataran Tinggi Jambi, eksplanasi yang dikaji berdasarkan paradigma prosesual ini terlihat dari hasil yang diperoleh dari penelitian sebelumnya. Misalnya, tentang hubungan distribusi megalitik dan kaitannya dengan situs lain seperti penguburan tempayan, atau bagaimana hubungan antara megalitik dengan unsur fisik di sekitarnya seperti dengan gunung, sungai, mata air dan kondisi topografi di sekitar situs.

Sebaliknya, lanskap dalam
perspektif paradigma pasca-
prosesual lebih menekankan pada
interpretasi terhadap tinggalan
arkeologis maupun terhadap unsur
alam seperti sungai dan gunung yang
ada di sekitarnya. Interpretasi ini
dapat didasarkan pada pandangan
individu (termasuk pandangan
peneliti) maupun pandangan
kelompok/ komunitas masyarakat di


sekitarnya yang digali melalui legenda dan tradisi lisan.

Kajian lanskap dalam perspektif ini mampu memberikan penjelasan khusus terhadap permasalahan lanskap yang tidak dapat dijawab dengan menggunakan perspektif prosesual. Misalnya saja permasalahan ketidakseragaman arah orientasi dan perbedaan lokasi penempatan megalitik.

\section{UCAPAN TERIMA KASIH}

Ucapan terima kasih penulis sampaikan sebesar-besarnya kepada Dr. Anggraeni dan Dr. Daud Aris Tanudirjo yang telah memberikan pemahaman baru kepada penulis mengenai kajian lanskap arkeologi. 


\section{DAFTAR PUSTAKA}

Anschuetz, Kurt F. dkk. 2001. "An Archaeology of Landscapes: Perspectives and Directions". Journal of Archaeological Research, 9 (2), 157-211

Ashmore, Wendy dan Bernard Knapp. 1999. Archaeologies of Landscape: Contemporary Perspectives. UK: Blackwell Publishers Ltd

Aziz, Fadhila Arifin. 2010. "Potensi Situs Arkeologi Kawasan Kerinci, Jambi: Ikon Budaya Austronesia". Amerta 28, 17-44

Aziz, Fadhila Arifin. 2012. "Karakter Peradaban Pedalaman Kerinci dalam Konteks Budaya Austro-Protosejarah". Dalam Tim IAAI, Arkeologi Untuk Publik (h. 642-667). Jakarta: IAAI Indonesia

Bonatz, Dominik dkk. 2006. "The Megalithic Complex of Highland Jambi: an Archaeological perspective". Bijdragen tot de Taal, Land-en Volkenkunde (BKI), 162 (4), 490-522

Bonatz, Dominik. 2012. "A Highland Perspective on the Archaeology and Settlement History of Sumatra". Archipel 84, 35-81

Budisantosa, T.M.S.2015. "Megalit dan Kubur Tempayan Dataran Tinggi Jambi dalam Pandangan Arkeologi dan Etnosejarah". Berkala Arkeologi, 35 (1), 17-32

https://doi.org/10.30883/jba.v35i1.36

Gosden, Chris dan Head, Lesley. 1994. "Landscape An Usefully Ambigous Concept”. Archaeology in Oceania, 29(3), 113-116

Greene, Kevin. 2003. Archaeology An Introduction. UK: Routledge

Guillaud, Dominique dkk. 2009. "Mounds, Tombs and Tales: Archaeology and Oral Tradition in South Sumatra Highlands". Dalam Bonatz dkk, From Distant Tales: Archaelogy and Ethnohistory in The Highlands of Sumatra (h. 416-433). UK: Cambridge Scholars Publishing.

Hodder, Ian. 1991. "Post-modernism, Post-structuralism, and Post-processual Archaeology". Dalam Ian Hodder, The Meanings of Things: Material Culture and Symbolic Expression (h. 64-78). New York: Harper Collins Academic.

Hodder, Ian. 2005. "Postprocessual and Interpretive Archaeology". Dalam Colin Renfrew dan Paul Bahn, Archaeology The Key Concepts (h.155-159). London and New York: Routledge 
Hodder, Ian, dan Hutson, Scott. 2003. Reading The Past: Current Approaches to Interpretation in Archaeology Edition 3. UK: Cambridge University Press.

Johnson, Matthew. 2007. Ideas of Landscape. USA: Blackwell Publishing Ltd

Sabloff, Jeremy. 2005. "Processual Archeology". Dalam Colin Renfrew dan Paul Bahn, Archaeology The Key Concepts (h. 159-164). New York: Routledge

Simanjuntak, H.T. 2008. Arkeologi, Arkeolog dan Iman. Dalam wawancara dengan Majalah DIA, edisi $1 . \quad$ Diunduh dari http://majalahdia.net/wawancara/arkeologi-arkeolog-dan-iman

Tanudirjo, Daud Aris. 2017. "Arkeologi Lanskap: dari Prosesual ke Pascaprosesual". Power Point Slides. Dipresentasikan pada 18 Mei di Yogyakarta.

Tilley, Christoper. 2005. "Phenomenological Archaeology". Dalam Colin Renfrew dan Paul Bahn, Archaeology The Key Concepts (h. 151-165). New York: Routledge

Tjoa-Bonatz, Mai Lin, 2009. "The Megaliths and The Pottery: Studying The Early Material Culture of Highland Jambi". Dalam Bonatz dkk., From Distant Tales: Archaelogy and Ethnohistory in The Highlands of Sumatra (h.196228). UK: Cambridge Scholars Publishing.

Layton, Robert dan Ucko, Peter. 1994. "The Archaeology and Anthropology of Landscape: Shaping Your Landscape”. UK: Routledge

Webster, Gary S. 2009. "Culture History: A Culture-Historical Approach". Dalam R.A. Bentley., C. Chippindale dan H. Maschner, Handbook of Archaeological Theories (h.11-27). Altamira: Plymouth

Wylie, Alison, 2002. Thinking From Things: Essays in The Philosophy of Archaeology. London: University of California Press 